\title{
Die Christelike filosofie van D.H.Th. Vollenhoven (1892-1978): Hoe dit ontstaan en verder ontwikkel het
}

\author{
Author: \\ Barend J. van der Walt ${ }^{1}$ \\ Affiliation: \\ ${ }^{1}$ School for Philosophy, \\ North-West University, \\ Potchefstroom Campus, \\ South Africa \\ Correspondence to: \\ Barend van der Walt \\ Email: \\ benniejvanderwalt@gmail. \\ com

\section{Postal address:} \\ 7 Bezuidenhout Street, \\ Oewersig, Potchefstroom \\ 2531, South Africa \\ Dates: \\ Received: 24 Nov. 2011 \\ Accepted: 29 Mar. 2012 \\ Published: 19 Mar. 2013 \\ How to cite this article: \\ Van der Walt, B.J., 2013, \\ 'Die Christelike filosofie van \\ D.H.Th. Vollenhoven (1892- \\ 1978): Hoe dit ontstaan en \\ verder ontwikkel het', In die \\ Skriflig/In Luce Verbi 47(1), \\ Art. \#80, 13 pages. \\ http://dx.doi.org/10.4102/ \\ ids.v47i1.80

\section{Copyright:} \\ (C) 2013. The Authors. \\ Licensee: AOSIS \\ OpenJournals. This work \\ is licensed under the \\ Creative Commons \\ Attribution License.
}

Read online:
Hierdie artikel is die eerste in 'n reeks van drie wat handel oor die ontstaan van 'n reformatoriesChristelike filosofie by D.H.Th. Vollenhoven (1892-1978), H. Dooyeweerd (1894-1977) van Nederland en H.G. Stoker (1899-1993) van Suid-Afrika. As algemene inleiding tot die trilogie word die vraag bespreek hoe hierdie filosofie vandag - 75 jaar na sy ontstaan - nog lewend en relevant kan wees. In hierdie eerste artikel, wat op die bydrae van Vollenhoven gefokus is, word die volgende behandel: (1) Ter inleiding word kortliks inligting oor sy persoonlikheid vermeld. (2) Aangesien veral kenteoretiese probleme in die brandpunt van belangstelling gestaan het ten tye van die geboorte van die reformatoriese filosofie aan die begin van die vorige eeu, volg 'n kort oorsig van hierdie wysgerige landskap. (3) Daarna word die moontlike invloede op Vollenhoven se denke van sowel buite (die sekulêre filosofiese milieu van sy tyd) as van binne (sy geesgenootlike tradisie) bespreek. (4) Die volgende hoofgedeelte vestig die aandag op Vollenhoven se pionierswerk vir sowel die die sistematiese filosofie as die filosofiese historiografie. (5) Dit word gevolg met 'n gedeelte oor hoedanig die nalatenskap van die driemanskap (Vollenhoven, Dooyeweerd en Stoker) deur daaropvolgende generasies ontvang is en hoe die reformatories-filosofiese tradisie verdeeld geraak het in die navolging van Vollenhoven, Dooyeweerd en Stoker. (6) Die verkenning word afgesluit met'n aanduiding van die noue verbintenis tussen Vollenhoven (sy persoon asook sy filosofie) en Suid-Afrika en in die besonder Potchefstroom.

The Christian philosophy of D.H.Th. Vollenhoven (1892-1978): How it originated and was developed. This article is the first in a series of three dealing with the emergence of a reformationalChristian philosophy in the work of D.H.Th. Vollenhoven (1892-1978), H. Dooyeweerd (1894-1977) of the Netherlands and H.G. Stoker (1899-1993) of South Africa. As a general introduction to the trilogy the question is how a tradition, the reformational philosophical tradition in particular, can today - 75 years after its inception - be kept alive and relevant. In this first article, focusing on Vollenhoven's contribution, the following are dealt with: (1) As introduction, something briefly is said about his personality. (2) Since especially epistemological issues were key problems at the cradle of his reformational philosophy during the first part of the previous century, a brief historical background (up to the present postmodern situation) is provided. (3) The third main section investigates the possible influences on Vollenhoven's thinking, firstly from outside (the philosophical environment of his times) and, secondly, from inside (preceding congenial thinkers). (4) Next, attention is asked for Vollenhoven's pioneering contribution to both systematic philosophy as well as the historiography of philosophy. (5) The following part deals with how the work of the triumvirate (Vollenhoven, Dooyeweerd and Stoker) was received by next generations and how the reformational philosophical tradition became divided into followers of Vollenhoven, Dooyeweerd and Stoker. (6) The reconnaissance is concluded with an indication of the close contacts between Vollenhoven as person as well as his philosophy and South Africa, especially Potchefstroom.

\section{Inleiding}

\section{Motivering hoe met 'n filosofiese tradisie omgegaan moet word, die beperking en die opset}

Tot die breë reformatoriese tradisie behoort ook die Christelike filosofie. Dit is 'n ryk tradisie wat tydens die dertigerjare van die vorige eeu gestalte gekry het. By die geboorte van hierdie wysbegeerte word gewoonlik die name van drie vaders genoem, naamlik D.H.Th. Vollenhoven (1892-1978) en H. Dooyeweerd (1894-1977) in Nederland en H.G. Stoker (1999-1993) in SuidAfrika. Hierdie tradisie in die filosofie bestaan vandag nog en het na meer as 'n driekwart eeu talle eksponente dwarsoor die wêreld (vgl. Van der Walt 2010a:127-151).

\section{Motivering}

Om verskillende redes (waarop in 'n latere artikel ingegaan sal word) is hierdie belangrike rigting in die filosofiese denkwêreld nie meer so bekend aan die jonger generasies van vandag as wat dit is 
vir die skrywer van hierdie bydrae nie - die skrywer is byna net so oud soos die tradisie self. 'n Belangrike motivering vir die skryf van hierdie en die twee opvolgende artikels is om iets van hierdie tradisie aan die jonger geslagte oor te dra. (Hierdie artikel begin met die bydrae van Vollenhoven en sal met die denke van Dooyeweerd en Stoker opgevolg word.)

As inleiding tot die reeks volg vooraf ' $n$ besinning oor dit wat 'n tradisie inhou en hoe ' $n$ mens daarmee behoort om te gaan om dit lewend en relevant te hou.

\section{Belangrike elemente van 'n tradisie}

Gegrond op die insigte van Wolterstorff (1987) kan die volgende vier elemente by enige tradisie onderskei word.

In die eerste plek is 'n tradisie 'n lewensbeskoulike, rigtinggewende interpretasie van die werklikheid wat 'n mens omring. Daarmee probeer ' $n$ mens verstaan wat is (of bestaan), maar ook hoe dit behoort te wees. In die geval van 'n filosofiese tradisie groei hierdie voorwetenskaplike tradisie uit tot 'n wetenskaplike besinning.

In die tweede plek vind 'n tradisie op talle maniere ook konkrete uitdrukking in die alledaagse lewe - die visie word werklikheid, dit bly nie 'n blote abstraksie nie.

Derdens kan 'n tradisie nie sonder 'n eie verhaal bestaan nie - dit moet (oor)-vertel word. Hoe het die geskiedenis daarvan verloop? 'n Filosofiese tradisie mag byvoorbeeld nie die grondleggers van die bepaalde stroming vergeet nie.

In die vierde plek moet steeds in gedagte gehou word dat elke tradisie - ook 'n Christelike tradisie - sowel die goeie as die minder goeie en selfs die verkeerde insluit. Die eenvoudige rede hiervoor is dat tradisie die maaksel van sondige mense is. ' $n$ Mens mag dus nooit by 'n tradisie wat feilbare mensewerk is, sweer nie. Terselfdertyd is 'n tradisie ook nie noodwendig heeltlemal verkeerd, sodat dit eenvoudig geïgnoreer of verwerp mag word nie. Hierdie besef bring 'n mens by die volgende belangrike punt:

\section{Hoe behoort met ' $n$ bepaalde tradisie omgegaan te word, sodat dit 'n lewende tradisie bly?}

Pelikan (1984:20) skryf die volgende: 'Tradition is the living faith of the dead, traditionalism is the dead faith of the living.' Omdat hierdie stelling waarheid bevat, is die dringende vraag hoe 'n lewende tradisie vir teenswoordige en toekomstige geslagte verseker kan word. Drie belangrike voor die hand liggende sake word hier genoem.

In die eerste plek moet 'n mens openheid toon, sodat 'n bepaalde tradisie jou kan voed of leer. Dit is 'n eerste vereiste selfs vir iemand wat sodanige tradisie eventueel verwerp. Terselfdertyd is 'n tweede vereiste ook nodig. Die tweede stap is kritiek - liefdevolle kritiek, maar nogtans kritiek. In die lig van wat hier bo oor 'n tradisie gesê is, sou die volgende drie kritiese vrae byvoorbeeld gestel kan word: Bied die tradisie 'n korrekte interpretasie van die werklikheid en dui dit nog 'n duidelike koers vir vandag aan? Vind dit uitdrukking in 'n eie lewenstyl of (in hierdie geval) in 'n eie filosofie? Word die verhaal van die tradisie wel vertel en gebeur dit op so 'n wyse dat dit gelowig-denkende mense van die een-entwintigste eeu aanraak, inspireer en motiveer?

Die derde stap is die kreatiewe uitbou van die tradisie. Dit moet nie net verbreed en verruim word nie, maar meestal ook gekorrigeer word in die lig van die feit dat enige tradisie die feilbare mensewerk van 'n bepaalde tyd is. In die reformatoriese tradisie is die idee van voortdurende reformasie (semper reformanda) goed bekend. Soos uit die titel van die wetenskaplike tydskrif van die Vereniging vir Christelike Filosofie (Philosophia Reformata, wat in 2010 reeds 75 jaar bestaan het) blyk, is dit ook die bedoeling van hierdie tradisie.

\section{'n Beperkte oogmerk}

In die lig van die voorafgaande sal in hierdie artikel iets van die reformatories-filosofiese tradisie meegedeel word. Die beperking op die artikellengte laat egter nie toe om al die fasette van hierdie tradisie te bekyk nie. Dit is onmoontlik om die verskillende filosofieë van hierdie drie grondleggers - dit wil sê, die inhoud van die hele tradisie - volledig hier te beskryf. Om hierdie leemte te ondervang, word egter soveel moontlik bronverwysings voorsien, sodat studente of navorsers wat nie op hoogte van al die beskikbare literatuur is nie, dit self kan bestudeer.

In wat volg, word dus hoofsaaklik gefokus op hoe die tradisie by hierdie drie denkers ontstaan en ontwikkel het nie die inhoud nie, maar die verhaal staan voorop. Dit verskaf die nodige openheid tot die tradisie. Verder sal ook duidelik gemaak word dat die tradisie reeds vanaf sy begin nie onkrities van aard was nie. Selfs die grondleggers daarvan het nie dieselfde filosofiese deuntjie gesing nie, maar het mekaar onderling gekritiseer. Die tweede en daaropvolgende generasies binne die tradisie stel ook nog indringender vrae. Op hierdie wyse is voldoen aan 'n verdere vereiste vir 'n lewende tradisie, naamlik die kreatiewe uitbou daarvan.

Hoewel 'n filosofiese tradisie nie dieselfde fases as die biologiese ontwikkeling van 'n mens volg nie, kan laasgenoemde tog as metafoor vir eersgenoemde gebruik word (vgl. Wolterstorff 1987:33). Wanneer 'n bepaalde filosofiese tradisie volwassenheid bereik, breek 'n moeiliker fase aan. Die vars entoesiasme van kindwees en puberteit is verby en so ook die opwinding en ontdekkings tydens adolessensie. By volwassenheid moet die drome en beloftes van die jeug waar gemaak word. Die reformatoriese filosofiese tradisie het alreeds die 75-jarige ouderdom verbygesteek. Beteken dit noodwendige 'n filosofiese Alzheimer-fase? Dit sou nie verbaas nie, aangesien filosofiese stromings gewoonlik nie soveel dekades oorleef nie.

Uit die volgende enkele resente voorbeelde blyk dit egter dat hierdie Christelike tradisie nie 'n eendagsvlinder is 
nie. Vergelyk slegs (behalwe talle artikels) die omvattende geskrifte van Strauss (2009) en Chaplin (2011) oor Dooyeweerd, die proefskrif van Tol (2010) oor Vollenhoven en dié van Ive (2012) oor Dooyeweerd en Vollenhoven asook die werk van Glas (2011). Oor Stoker skryf Van der Walt (2009) 'n skripsie.

\section{Opset}

Na hierdie algemene inleidende besinning oor hoe om met 'n tradisie om te gaan, kan nou op die tradisie met betrekking tot Vollenhoven gefokus word. Agtereenvolgens sal aan die volgende aspekte aandag gegee word: (1) Sy persoonlikheid; (2) Die filosofiese landskap (veral die kenteoretiese) ten tye van die ontstaan van die reformatoriese filosofie; (3) Mootlike invloede op die denke van Vollenhoven (sowel vanuit die destydse sekulêre omgewing as vanuit sy eie tradisie); (4) Vollenhoven se pionierswerk op die gebied van sistematiese en historiese filosofie; (5) Die verdere ontwikkeling van die reformatoriese filosofie deur daaropvolgende generasies in verskillende (Vollenhoveniaanse, Dooyeweerdiaanse en Stokeriaanse) skole; en (6) Die kontak tussen die denke van Vollenhoven en Potchefstroom in Suid-Afrika.

\section{Persoonlikheid}

Hoewel boeiend, ontbreek die ruimte om op die lewensgeskiedenis van Vollenhoven in te gaan. Daarvoor word die belangstellende leser na die biografie van Stellingwerff (1992) asook die artikel van Bril (1978) verwys.

Hoewel 'n mens se filosofie nie noodwendig 'n weerspieëling van jou persoonlikheid is nie, bestaan daar tog 'n verband daartussen. Hoe beskry f persone wat Vollenhoven goed geken het hom as mens?

Klapwijk (1987), wat Dooyeweerd en Vollenhoven nog persoonlik geken het, het die nageslag 'n guns bewys deur kort sketse oor hulle persoonlikhede en filosofieë (en ook oor die van hulle eerste generasie navolgers) te skryf. Dit gaan hier primêr oor Vollenhoven, maar deur 'n vergelyking met Dooyeweerd word die profiel van Vollenhoven duideliker.

\section{Verskillende persoonlikhede}

Vir Klapwijk (1987) was Dooyeweerd die aristokraat, terwyl Vollenhoven 'n denkreus was, maar terselfdertyd ook méér:

Tegen Vollenhoven zag menigeen op als een reus, een denkreus ... maar Vollenhoven, de reus had ook iets van een kind. Hoezeer professor, toch was hij de eenvoud zelf, ongekunsteld en ongecompliseerd. Hij stond vlak bij zijn mensen, zijn studenten, zijn geestverwanten. Hij volgde wie hem niet volgen kon ... (bl. 99)

Vanwaar hierdie nederige houding? Klapwijk verduidelik verder:

Niet aan de wijsbegeerte maar aan het Woord heeft deze filosoof zijn hart verpand ... Het Woord is vast ... Dus heeft de wijsbegeerte de wijsheid niet in pacht. Wijsbegeerte is begeertenaar-wijsheid, niet minder, ook nie meer. Geen wijsgeer kan deze begeerte uit eigen voorraad bevredigen ... Het Woord alleen geeft antwoord ... Ik ga een beetje begrijpen waarom Vollenhoven, de grote geleerde, in zijn hart een kind gebleven is. (bl. 101; vgl. ook Klapwijk 1992)

Reeds op 14 Desember 1935, by die stigtingsvergadering van die Vereniging voor Calvinistische Wijsbegeerte, sê Vollenhoven as voorsitter dat dit nie die wysbegeerte is wat die mense van die vereniging bymekaargebring het nie, maar iets veel belangrikers:

Het is niet de wijsbegeerte, want die is niet het eerste in ons leven. Het is veeleer de band aan Gods Woord, omdat wij door genade hebben geleerd alleen uit Christus te willen leven, en de religie als hartezaak de kern is geworden van heel ons bestaan; omdat we hebben geleerd, dat alleen in het letten op de geboden des Heren vrede en leven is te vinden, niet alleen voor de enkeling, maar vanzelf ook voor alle lewensverbanden in welke wij staan. Daarom is de Wijsbegeerte niet nummer één. Zo is het nooit geweest in onze kring ... Wij willen slechts ernst maken met de hoofzaak, óók in de wijsbegeerte. (Van Dijk \& Stellingwerff 1961:94)

\section{Verskillende filosofieë}

Bogenoemde verklaar tot 'n mate ook die verskille tussen die twee filosofieë. Weer word Klapwijk (Puchinger 1980) aan die woord gestel:

Het was Dooyeweerd's bedoeling geweest om te filosoferen vanuit een Christelijke, reformatorische inspiratie, vanuit de zo geheten Christelijk-religieze grondmotief van schepping, zondeval en verlossing. Vollenhoven, daarentegen wil filosoferen uitgaande van twee kennisbronnen: de natuur (de empirische wereld) en de Schriftuur (de bijbel) ... Dooyeweerd benadrukte de religieuze inspiratie,. Vollenhoven de bijbelse informatie. (bl. 220; vgl. ook Klapwijk 1980:559)

Volgens Klapwijk vertoon albei maniere van filosofeer egter ook swak kante. Dooyeweerd - bang vir die moontlike beskuldiging van 'n gekamoefleerde teologie of die vermenging van wysbegeerte en teologie - het homself algaande minder op konkrete bybelse uitsprake beroep. Daarteenoor meen Klapwijk dat Vollenhoven dalk empirieswetenskaplike uitsprake vermeng het met sy besinning op die bybelse boodskap. (Die belangrike vraag van hoe presies die Bybel in 'n Christelike filosofie gebruik mag word, kom hier dus na vore.)

Ek sou nog wou byvoeg dat Dooyeweerd veral breë sistematiese lyne getrek het, terwyl Vollenhoven die Kleinforscher van die geskiedenis van die filosofie was. In 'n beeld gestel: Dooyeweerd het met 'n wyehoeklens na die werklikheid gekyk, terwyl Vollenhoven, veral in sy latere jare, deur sy (filosofiese) mikroskoop die geskiedenis van die Westerse denke bekyk het.

\section{Dieperliggende verskille}

Vollenhoven was nie, soos sommige navorsers van mening is, 'n leerling, navolger of blote medewerker (vgl. Chaplin 2011:330 voetnoot 16) van Dooyeweerd nie. Dooyeweerd was wel internasionaal meer bekend, maar eintlik het Dooyeweerd, wat geen formele opleiding in die Filosofie gehad het nie (hy het in die Regte gepromoveer), 
aanvanklik by Vollenhoven se filosofie kers opgesteek (vgl. Tol 2011:199-201). Mettertyd het hulle filosofiese ontwikkeling egter verskillende paaie geloop.

Hierdie verskille is egter nie aan die groot klok gehang nie. Vollenhoven was terdeë bewus van hulle onderlinge verskille - ook al het hy dit eers later (ongeveer 1953) uitgespreek en dit dan nog steeds as vertroulik (slegs vir interne diskussie) beskou. Die teks wat hierdie verskille uitspel, heet Divergensierapport en is te vind in Vollenhoven (1992:107-117).

Twee van die belangrikste verskille is die volgende: eerstens dat Vollenhoven tussen God, wet en kosmos onderskei, terwyl Dooyeweerd net God en kosmos onderskei. By kosmos maak Dooyeweerd ook nog 'n onderskeid tussen die wetsy en die subjeksy. Die tweede verskil is die onaanvaarbaarheid vir Vollenhoven van Dooyeweerd se idee van die bo-tydelikheid van die menslike hart. Hierdie twee grondliggende verskille het groot implikasies vir sowel Dooyeweerd as Vollenhoven se filosofie gehad. Dit sou ook later tot verdeeldheid by die navolgers van hierdie twee vaders lei (vgl. die reaksie van volgende gererasies wat later bespreek word).

In die volgende punt word op die gemeenskaplike filosofiese klimaat gelet waarin altwee hierdie denkers gefilosofeer het. Daarna sal nagegaan word watter filosofiese invloede spesifiek by Vollenhoven ' $n$ rol gespeel het.

\section{Die filosofiese (kenteoretiese) landskap ten tye van die ontstaan van die reformatoriese filosofie}

Die tyd waarin Vollenhoven, Dooyeweerd en Stoker geleef en gedink het, was 'n oorgangsperiode tussen die laaste fase van die laat-Rasionalisme (neo-idealisme genoem) en die opkoms van die Irrasionalisme (veral die lewensfilosofie, die eerste stroming binne die Irrasionalisme).

By die rasionalistiese filosofie (met klem op 'n verabsoluteerde rede) het die kenteorie in die brandpunt van die belangstelling gestaan. By die drie vroeëre rasionalistiese stromings is die inhoud van wetenskaplike kennis veral beklemtoon, terwyl die laat-rasionaliste se aandag gevestig was op die metodes van hoe 'n mens tot kennis kom. In die geval van die driemanskap sien 'n mens die aansluiting by hierdie metodologiese tendens duidelik. Ons vind dit by Vollenhoven in sowel sy sistematiese filosofie as in sy wysgerige historiografie. Dooyeweerd se transendentale metodes is bekend, terwyl Stoker selfs ' $\mathrm{n}$ afsonderlike werk oor metodes geskryf het (vgl. Stoker 1961).

Vervolgens 'n historiese intermezzo om die hele kenteoretiese probleem in 'n breër perspektief te plaas.

\section{Verskillende argumente teen neutrale denke}

Die Irrasionalisme wat ten tye van die drie vaders aan die opkom was, oorheers vandag die toneel in die vorm van die sogenaamde Postmodernisme. Wat Stoker, Vollenhoven en Dooyeweerd alreeds in die dertigerjare van die vorige eeu beklemtoon het, naamlik dat neutrale denke onmoontlik is, word vandag algemeen aanvaar. Anders gestel: die rasionalistiese idee dat die subjek (kenner) in sy bestudering van die objekte onbevooroordeeld en objektief kan en moet wees, word radikaal verwerp.

Let egter daarop dat die redes waarom die reformatoriese vaders en die postmoderniste neutraliteit verwerp, totaal verskillend is. Die drie reformatoriese denkers kon die neutraliteitsdogma van die Rasionalisme ontmasker en vanuit hulle Christelike geloof bestry, omdat hulle daarvan oortuig was dat ' $n$ mens se hartsoortuiging (in gehoorsaamheid aan God of nie) ook jou logiese denke bepaal. Postmoderniste, daarenteen, staan nog steeds - of hulle dit wil erken of nie in 'n eeuelange tradisie van geloof in die outonomie van die mens en sy denke. Die mens word dus as sy eie wetgewer beskou - 'n interne kontradiksie, omdat 'n mens nie tegelyk wetgewer en onderdaan, baas en klaas kan wees nie.

\section{Die historiese verloop in voëlvlug}

Eenvoudigheidshalwe gaan ek hier van die volgende onderskeiding uit: (1) die kenner (tradisioneel die subjek genoem) rig (2) sy kenaktiwiteit volgens (3) spesifieke metodes op (4) iets kenbaars (tradisioneel die objek genoem) en bereik (5) 'n kenresultaat (kennis genoem). In die loop van die geskiedenis is die klem egter afwisselend óf op die kenner óf op die kenbare gelê. Tydens die laat-rasionalistiese klimaat waarin die driemanskap se filosofieë ontstaan het, was alle aandag meestal op die kennende rede en sy metodes van kennisverwerwing toegespits.

\section{Kennis van die wet}

'n Veel belangriker vraag wat agter hierdie debat lê, is wat presies dit is wat (wetenskaplik) geken word: die wetmatigheid of die normatiwiteit ten grondslag van alles. Die kenteoretiese probleem word dus hier nie volledig bespreek nie, maar dit word slegs vlugtig aangetoon hoe daar nou al vir 2500 jaar na kennis van die wette of norme gesoek word wat rigting aan denke en handeling moet gee.

\section{Die begin van Subjektivisme}

Die antieke Griekse denker, Plato, het die wette as selfstandige, afsonderlike 'idees', apart van die werklikheid beskou en hulle probeer ken (bv. die idee van die ware vir die wetenskap). Spoedig na hom verval die Griekse denke egter in Subjektivisme. Daarmee word aan die wette of norme vir dink en doen nie meer 'n eie, aparte, geldige bestaan toegeken nie, maar dit word gesoek in die dinge self. Die hele Westerse filosofie daarna dink op hierdie wyse subjektivisties. Al verskil is presies waar (in watter dinge) hulle die normatiewe riglyne probeer vind.

\section{Die rede as leidster}

$\mathrm{Na}$ die klassieke Griekse denke, reeds gedurende die Hellenistiese filosofie, volg 'n tweede stap: normatiwiteit 
word van buite na binne (apriories) in die mens se denkgees geplaas. Nou begin die epistemologie nog sterker op die voorgrond tree. Eeue later maak die Rasionalisme (1600-1900) daarvan 'n Rede (verabsoluteerde verstand). Die Rede sou die regte rigting na 'n wonderlike toekoms aandui en dit bowendien op 'n neutrale, onbevooroordeelde, objektiewe wyse (deur wetenskaplike kennis) doen. Aan die Rede word dus goddelike openbaringskrag toegeken.

\section{Irrasionalistiese stromings}

Toe hierdie hoë ideaal reeds teen ongeveer 1900 'n lugspieëling blyk te wees, kom daar irrasionalistiese reaksie. Dit beteken nie dat redelikheid heeltemal verwerp kon word nie - dan sou irrasionaliste moes ophou filosofeer en lywige boeke publiseer, maar slegs dat die rede nou gedegradeer word (vgl. Kok 1998:171). (Dit is onder andere die rede waarom baie denkers vandag meen dat die Postmodernisme nie 'n radikale breuk met die modernistiese rasionalisme is nie, maar bloot 'n andersoortige voortsetting daarvan.) Die onbybelse strewe na menslike outonomie deur middel van menslike denke bly dus voortbestaan. God se norme vir die lewe word nog steeds ontken. Al verskil is dat die Irrasionalisme die praktyk bo die teorie stel (sonder om laasgenoemde te verwerp). In die sogenaamde praktiese lewe word, subjektivisties, na norme gesoek. By die lewensfilosofie kom die mag van lewe aan die orde, terwyl dit by die pragmatisme die nuttigheid en by die eksistensialisme menslike, outonome vryheid is waarop gefokus word.

Die geskiedenis het egter reeds bewys dat sodanige norme katastrofiese gevolge (soos twee wêreldoorloë) kan hê. Dit is die rede waarom dit vandag as onderdrukkende, groot verhale afgeskryf word. In die plek daarvan moet egter na ander norme gesoek word, want geen mens kan sonder riglyne dink of lewe nie.

\section{Postmodernisme}

Ek kan hier slegs enkele voorbeelde noem van hoe die postmoderne denke opnuut normatiewe vastigheid probeer soek. (Vir 'n kort oorsig, vgl. Kok 1998:164-172, en vir meer besonderhede vgl. Middleton \& Walsh 1995 en Van der Walt 2008b:128-166.)

Gadamer (vgl. Derksen 1983) soek dit in die betekenis van taal, waaragter 'n objektiewe, universele sisteem moontlik skuil. Met sy dekonstruksieteorie vernietig Derrida egter die gedagte dat 'n teks net een vaste betekenis kan hê. Dit het volgens hom soveel betekenisse as wat daar lesers is. Foucault (vgl. Bertels 1972) volg dié taalspel tot in sy finale konsekwensies van die ontbinding van die self. Die neopragmatis, Rorty, probeer opnuut om normatiewe vastigheid in 'n mens se eie kultuur en samelewing of web van voorstellings te vind. Taylor (vgl. Heyns 2002) gryp in baie opsigte terug na die Christelike elemente van sy Katolieke geloof, omdat hy waarskynlik intuïtief besef dat dit tog nog 'n vaste punt bied. Blykbaar het Augustinus se woorde in sy geval waar geword, naamlik dat die menslike hart (en dus ook sy verstand) nooit rus vind nie, tensy dit vastigheid vind in God.
Saamgevat: nóg die rede, nóg taal, nóg die menslike gemeenskap, nóg die neo-skolastiek - niks in hierdie werklikheid - kan vir die sekulêre denke van vandag enige blywende normatiewe koers bied nie. Wat die toekoms betref, kan verwag word dat slegs nuwe fasette van die skepping tot vae waardes verabsoluteer gaan word (vgl. Van der Walt 2010d, 2010e).

\section{Gevolgtrekking}

Kok (1998) kom vervolgens aan die woord oor sowel Modernisme (Rasionalisme) as Postmodernisme en ek stem heelhartig met hom saam:

Reason enthroned or dethroned will not save us. The choice is not between modernism and postmodernism, between rationalism and irrationalism. Just as Christians must radically reject the modernist move towards the self-reflective, self-determining, autonomous subject who stands outside any tradition or community and is subject to no one, so also they must reject the postmodernist celebration of construction, collage, and juxtaposed practice. (bl. 172)

Dit gaan vandag - ook in die kenteorie - nog steeds ten diepste oor die plek, aard en gesag van die wet of die normatiewe riglyne vir die hele lewe. Omdat daaroor nie meer duidelikheid bestaan nie, is die Westerse mens sy koers kwyt. Dit sluit myns insiens ook die kerklike lewe in, wat dikwels nie meer normatiewe rigting aan hulle lidmate vir die lewe van elke dag bied nie. Die skrywer het probeer (vgl. Van der Walt 2008b) om die agtergrond van hierdie postmoderne krisis en 'n moontlike Christelike antwoord daarop na te gaan (vgl. verder ook Van der Walt 2010g).

\section{Moontlike beïnvloeding}

Na hierdie breë ekskursie is die volgende fokuspunt die meer spesifieke moontlike invloede op Vollenhoven se denke. In aansluiting by wat pas oor die filosofiese dampkring van sy tyd gesê is, word eers moontlike eksterne invloede en daarna waarskynlike interne invloede, naamlik die Christelike tradisie waarin Vollenhoven gestaan het, hanteer.

\section{Moontlike invloede van buite}

Die studies van Kok $(1992)$ en Tol $(2010,2011)$ toon duidelik aan hoe Vollenhoven se Christelike filosofie nie maklik en in 'n kits tot stand gekom het nie. Dit het die harde denkworsteling van jare en die kritiese oorweging van die visies van talle filosowe geverg. Sy eie teties-kritiese metode impliseer dat hy wel 'n eie standpunt as vertrekpunt noodsaaklik beskou het, maar dit impliseer nie dat hy as Christelike denker van mening was dat hy niks (in sowel negatiewe as positiewe $\sin$ ) van ander kon leer nie. Reeds in sy proefskrif (vgl. Vollenhoven 1918) sluit hy vir sy idees oor 'n viervoudige intuïsie byvoorbeeld aan by die filosofie van Bergson. Tol (2010) het ook aangetoon hoe Vollenhoven aanvanklik 'n semi-skolastieke, semi-realistiese filosofie toegedaan was.

Puchinger (aangehaal in Van Dijk \& Stellingwerff 1961:89) noem ' $n$ hele aantal ander denkers wat Vollenhoven later 
gedurende sy predikantskap bestudeer het. Tydens sy bedieningstyd in sy eerste gemeente in Oostkapelle lees hy onder andere Poincaré, Rickert, Einstein, Driesch en die Marburgse Neo-Kantiane. Met 'n studiebeurs kon hy in 1920 die klasse van F. Krüger in Leipzig volg. Daar het hy die geleentheid gehad om ook met die metode van Wundt kennis te maak. Nadat hy in 1920 'n beroep as predikant na Den Haag aanvaar het, word sy studie in die Wysbegeerte voortgesit.

Vollenhoven erken self dat die Calvinistiese wysbegeerte 'zijn heengegaan door' die Marburgers en Husserl (d.w.s. die neo-idealisme) en 'hier en daar haar sporen (zijn) nagelaten' (Vollenhoven 1992:112).

Om hierdie hier en daar ... nagelate spore binne die beperkte ruimte van een artikel presies vas te stel, is onmoontlik. Dit sal nog baie meer navorsing verg as die reeds genoemde navorsing van Kok en Tol. Daarbenewens was die invloed van bogenoemde denkers ook wisselend. (Die invloed van Poincaré en Bergson was veel groter as dié van Krüger in Leipzig - daarvan kan geen latere spoor by Vollenhoven gevind word nie.)

\section{Moontlike invloede van binne die eie kring}

Die leser word daarop gewys dat die woord moontlike (invloede) ook hier belangrik is. Die tradisie waarin die driemanskap staan, gaan ver terug in die geskiedenis tot by die sestiende-eeuse Reformasie. Die driemanskap beroep hulle graag daarop dat hulle by Calvyn se denke aansluit.

Kort na Calvyn (reeds by sy opvolger, Beza) verval die reformatoriese denke ongelukkig in skolastieke ortodoksie. Eers gedurende die agtiende en negentiende eeu kom daar weer herlewing - die Réveil genoem. Hierdie stroming dra by tot 'n merkwaardige Christelike herlewing, eers by Kuyper en later ook in die filosofie van Vollenhoven en Dooyeweerd.

\section{Die Réveil}

Hierdie beweging (vgl. Kluit 1960:627-629 en ook 1970) was 'n geestelike oplewing gedurende die laat-agtiende- en eerste helfte van die negentiende eeu in Wes- en Midde-Europa. Dit was 'n reaksie teen deïstiese rasionalisme, teologiese dogmatisme en 'n verstarde, vervalle kerklike lewe. Nie dorre, skolastieke dogmatiek nie, maar ware bekering was 'n eerste vereiste vir herlewing. Ernstige Bybelstudie moes die uitgangspunt vir ' $n$ waarlik vroom lewe wees. Die Bybel is in gesinsopset en in groepies bestudeer en het Christene se oë vir hulle naaste en die breë samelewing oopgemaak.

Sommige van die leiers van hierdie beweging in Nederland was Bilderdijk (1756-1831), Da Costa (1798-1860) en Groen van Prinsterer (1801-1876). Hoewel die beweging oor die hele Wes-Europa versprei was, beperk ons ons in hierdie artikel tot die Nederlande (vgl. Kluit 1970:125 e.v.), tot die digterdenker, Bilderdijk, en die staatsman, Groen van Prinsterer as twee verteenwoordigers daarvan (vir besonderhede oor Da Costa, vgl. Overduin 1957).
Bilderdijk en Groen van Prinsterer: Vir Bilderdijk se agtergrond, lewe en werk kan Smilde (1956) nageslaan word. Bosch (1961:228-229) toon aan hoe nóú Bavinck (1906), maar veral ook Kuyper by Bilderdijk se religieuse grondkonsepsie aangesluit het en sien reeds by Bilderdijk in beginsel die totaliteitsvisie van 'n Calvinistiese lewensbeskouing en filosofie. Verskillende invloede is in Bilderdijk se denke te bespeur soos byvoorbeeld dié van Augustinus, Calvyn, Pascal, die Duitse romantiek se natuurbeskouing, Leibnitz, Schelling en so meer. Hy is ook krities teenoor die rasionalisme se sisteemdenke en verabsoluteer (volgens Bosch) daarteenoor die mens se selfgevoel.

Bosch (1961:233-234) noem egter die volgende ooreenkomste met dit wat later sou volg: (1) Bilderdijk se klem op die menslike hart as die kern van die menslike persoonlikheid, waarin die roepstem van God gehoor word. (2) Sy eerbied vir God se wette of verordenings. (3) Die selfgenoegsaamheid van die Skepper en die onselfgenoegsaamheid van die skepping. (4) Die geloof as 'n ingeskape funksie by alle mense. (5) Die gerigtheid van sy denke op God as die Oorsprong. (6) Hy verwerp die outonomie van die mens en sy denke, wil en gevoel - alleen die Heilige Gees gee ware kennis. (7) Hy bevraagteken rasionalistiese abstraksies. (8) Hy verwerp die skeiding tussen natuur- en geesteswetenskappe. (9) Christus is die Bron en Middelpunt van ware kennis en wysheid buite Hom bestaan geen ware kennis nie. (10) Erkenning van Christus se heerskappy op aarde vorm die kern van Bilderdijk se visie op die geskiedenis.

Vir 'n kort oorsig oor Groen van Prinsterer se agtergrond, lewensgeskiedenis en werk kan Scholten (1958) geraadpleeg word en vir meer detail Schutte (1977) en Van Dyke (1989). Groen van Prinsterer sit Bilderdijk se werk voort deur Christene daaraan te herinner dat hulle God se Woord moet erken en só die verdiepende kulturele krisis van Europa as gevolg van godsdienstige sekularisasie moet bestry. Reeds 'n jaar voor Marx se bekende Kommunistiese Manifes publiseer Groen van Prinsterer in 1847 sy werk Ongeloof en revolusie (vgl. Groen van Prinsterer 1951, 1973, 1975). Daarin toon hy aan hoe die ongeloof van die Weste revolusie voortbring, terwyl die Christelike geloof reformasie nastreef. Hy begin met Christelike skole en 'n Christelike politieke party. Sy passie om 'n voltydse navolger van Christus op elke lewensgebied te wees, dra hy ook aan Kuyper oor wat sy werk op 'n nog groter skaal sou voortsit.

Vyf stappe: Van Dyke (2001) toon aan hoe Kuyper (en later Vollenhoven en Dooyeweerd) nie van die grond af begin het nie, maar in sy teologie by 'n tradisie wat reeds 'n eeu oud was, kon aansluit. Die eerste twee belangrike fondamente was reeds gelê. In die eerste plek grondige bekering en in die tweede plek herlewing of die geloofsgroei van 'n groot deel van die bevolking. In die derde plek het 'n eiesoortige Christelike lewensvisie begin gestalte kry waarop Kuyper (1899) later kon voortbou (vgl. Heslam 1998). Dit het ten tye van Kuyper die vierde stap moontlik gemaak, naamlik reformasie. Runner (1982) beskryf hierdie laaste stap soos volg: 
A reformation is a revival so radical and widespread that it affects the direction of the culture and the structuration of society ... the redeeming power of the gospel is brought to bear on the entire life of the people of God. (agterblad)

Stoker, Vollenhoven en Dooyeweerd kon op hierdie vier fondamente bou en 'n vyfde sport bereik, naamlik op wetenskaplike vlak. Hulle het, anders as Kuyper, die implikasies van 'n voorwetenskaplike, Christelike lewensvisie ook op die gebied van die Wysbegeerte uitgewerk, aangesien dit die grondslag kon bied vir hervorming in die ander wetenskappe.

Dit bring ons by die moontlike invloed van figure nader aan die tyd van Vollenhoven.

\section{Invloed van Kuyper (1837-1920)?}

Vollenhoven het beslis ook Kuyper gelees en van hom geleer, hoewel hy dit uitdruklik stel dat daar in Kuyper se denke ook aspekte is wat nie ooreenstem met die Woord van God nie (vgl. Van Dijk \& Stellingwerff 1961:95). Hoewel Vollenhoven in 1918 as gevolg van Woltjer se dood (in 1917) onder Geesink gepromoveer het, was sy werklike leermeester J. Woltjer. Woltjer was veral vir sy logosspekulasie bekend (vgl. Van der Laan 2000 en Kok 2007).

\section{Invloed van Woltjer (1849-1917)?}

Nijhoff (2011a) toon eers aan dat Vollenhoven Woltjer gekritiseer het:

Vollenhoven ... criticised his logocentric correlation of ontological and epistemological notions. In this speculation he perceives a crossing of the boundary between Creator and creation. Vollenhoven himself proposed an epistemology in which both the knower and the known object are subject to norms that hold for the 'knowledge relation' between them. (bl. 5; vgl. ook Nijhoff 2011b).

Nijhoff glo egter nie dat Vollenhoven aan Woltjer ten volle reg laat geskied het nie. Waar Vollenhoven 'n groot verskil tussen sy eie filosofie en dié van sy leermeester gesien het, kies Nijhoff eerder vir 'n groot mate van kontinuïteit (vgl. Nijhoff 2011b). Dalk word die probleem opgelos deur twee fases in Woltjer se denke te onderskei (vgl. Vollenhoven 2005b:441-442). Vollenhoven was krities teenoor Woltjer se vroeëre konsepsie, maar nie soveel teenoor die tweede, waarin Woltjer na 'n pneumatologiese wisselwerkingsteorie oorgegaan het nie (vgl. Vollenhoven se tipering van sy eie, meer finale filosofiese standpunt hieronder).

\section{Invloed van Geesink (1854-1929)?}

Klapwijk (1980:545 en 456) maak die opmerking dat Geesink alreeds die onderskeid tussen God-wet-kosmos gemaak het waarin Vollenhoven hom later sou volg. Dit was dus nie so 'n oorspronklike ontdekking van laasgenoemde soos nog dikwels gedink word nie. Tol (2010) bevraagteken hierdie stelling egter.

\section{Invloed van Janse (1890-1960)}

Alhoewel daar nog onsekerheid bestaan oor die invloed van Woltjer en Geesink op Vollenhoven, hoef daar nie meer getwyfel te word oor die invloed van A. Janse van Biggekerke nie. Daarop wys Bril reeds in 1982 (vgl. Vollenhoven 1982:110-116). Van der Walt (2008a) skryf daaroor (oorspronklik reeds in 1989) en Tol (2010:224-262, 2011:203-205) staaf Janse se invloed in detail.

Daar word vertel dat Geesink (Vollenhoven se promotor) nie veel van Vollenhoven se proefskrif (1918) kon verstaan nie. Van 'n eenvoudige onderwyser uit 'n afgeleë plekkie (Biggekerke) ontvang Vollenhoven egter kort na sy promosie indringende kommentaar van nie minder as 25 bladsye nie op sy proefskrif. Janse se meer bybelse mensvisie, in plaas van die oeroue digotomistiese (siel en liggaam) of trigotomistiese (siel, liggaam en gees) mensvisie, is deur Vollenhoven aanvaar met groot konsekwensies vir sy hele filosofie. Janse se invloed op Vollenhoven moet egter nie oorskat word nie.

\section{Vollenhoven as pionier van die reformatoriese denke}

Al die voorafgaande gedagtes en stromings vloei uiteindelik bymekaar in die een Vollenhoveniaanse stroom. Dit word egter nie 'n onduidelike mengsel daarvan nie - Vollenhoven was gekant teen enige sintese-denke, maar dit mond uit in iets nuuts en oorspronkliks.

In plaas daarvan om Vollenhoven se filosofie hier uiteen te sit (vgl. die verskillende bronne daaroor in die bibliografie aan die einde van hierdie artikel), word hier op die nuwe bydraes, pionierswerk, gefokus wat hy ten opsigte van sowel die sistematiek as die geskiedenis van die Filosofie gemaak het.

Vooraf net die volgende opmerking: Vollenhoven word dikwels as onverstaanbaar beskou. Wanneer 'n mens egter eers die basiese trekke van Vollenhoven se filosofie verstaan, is dit nie meer moeilik volgbaar nie. Die ingewikkeldheid daarvan is meer toe te skrywe aan Vollenhoven se kompakte styl (hy gebruik geen woord onnodig nie) en sy eie terminologie om die komplekse geskiedenis van die Westerse denke baie noukeurig (meer as wat gewoonlik die geval is) te beskrywe.

\section{'n Nuwe sistematiek}

Vollenhoven wou nie net as ' $n$ Christen filosofie beoefen nie. Hy wou 'n Christelike filosofie daar stel. Nuwe perspektiewe in sy sistematiese filosofie was onder andere die volgende (vir besonderhede vgl. Vollenhoven 2005c, 2010):

Vollenhoven breek (negatief) - reeds lank voor die Irrasionalisme en huidige Postmodernisme - met die gedagte van neutrale wetenskapsbeoefening en dui (positief) 'n duidelike Christelike rigting aan.

Hy bevraagteken ook die skolastiese sintese-denke wat gedurende sy tyd in die kerk en teologie nog hoogty gevier het en verwerp daarom die dualisme van natuur en genade, wete en geloof en die talle implikasies daarvan. 
Hy kritiseer ook die eeue oue dualistiese en monistiese filosofieë (waarvan eersgenoemde uiteindelik tot deïsme lei en laasgenoemde dikwels in panteïsme eindig) en vervang dit met 'n radikale ontologiese onderskeid, maar met noue religieuse samehang, tussen God, sy skepping en sy wette vir die skepping. Sy onderskeid tussen die sentrale liefdesgebod, die struktuurwette en die menslik gepositiveerde norme (die brug tussen eersgenoemde twee) is ook belangrik.

In Vollenhoven se antropologie breek hy (soos reeds genoem) met ' $n$ meer as tweeduisendjarige tradisie, waarvolgens die mens uit liggaam en siel (digotomie), of liggaam, siel en gees (trigotomie) sou bestaan. Dit open nuwe perspektiewe op talle probleme soos byvoorbeeld oor die betekenis daarvan om God se beeld te vertoon, die liefdesgebod kon ook weer sy sentrale plek vind, en nog meer.

Vollenhoven se teorie van verskillende fasette, funksies of modaliteite (wat hy saam met Dooyeweerd en Stoker ontwikkel het) blyk een van die vrugbaarste, praktiese onderdele van sy sistematiese filosofie en mensbeskouing te wees.

Uit die nuwe antropologiese vertrekpunte vloei ook 'n nuwe samelewingsfilosofie met gedifferensieerde menslike verantwoordelikhede in verskillende verbande, asook 'n skerper omlyning van begrippe soos amp, roeping, gesag, mag en verantwoordelikheid.

Hy kom verder met 'n ander epistemologie na vore wat die klem nie eensydig op óf die kenner, óf die kenbare lê nie, maar die onderskeid en verband tussen kenner, kenaktiwiteit, kenbare en kenresultaat aantoon.

Vollenhoven wou nie bloot anti-teties filosofeer nie (dit beteken dat hy summier alles wat andersdenkendes geleer het, sou verwerp), maar anti-sinteties (hy het gestry teen alle pogings om die bybelse openbaring met onbybelse gedagtes te vermeng). Hy pas dus 'n eie teties-kritiese metode toe, soos uiteengesit in die afdeling oor moontlike invloede van buite wat hierbo behandel is. Dit beteken kortliks dat ' $n$ mens nie sonder 'n voorlopige eie standpunt kan filosofeer nie, of die eeue lange geskiedenis van die filosofie kan bestudeer nie. Terselfdertyd moet ' $n$ mens egter hierdie eie (sistematiese) vertrekpunt voortdurend toets aan 'n grondige studie van wat die geskiedenis van die Westerse filosofie opgelewer het om dit (die standpunte wat jy teëkom) óf negatief te verwerp, óf positief ter verdere verheldering van jou eie visie aan te wend.

Dit bring ons by Vollenhoven se tweede belangrike bydrae:

\section{'n Oorspronklike filosofiese historiografie}

Aangesien Vollenhoven se eie geskrifte hieroor beskikbaar is (vgl. Vollenhoven 2000, 2005a, 2005b) en ek self hieroor reeds 'n elementêre inleiding gegee het (vgl. Van der Walt 2010c), hoef dit nie hier verder verduidelik te word nie. In enige wetenskap speel metode(s) 'n belangrike rol. Metodes is nie neutraal nie, maar bepaal 'n mens se resultate. (vgl. Venter 1981:501 e.v. vir 'n deeglike besinning oor die presiese inhoud en veronderstellings van wetenskaplike metodes.) Vollenhoven het myns insiens met sy probleemhistoriese metode daarin geslaag om ' $n$ metode te ontwerp wat wysgerig van aard is, maar terselfdertyd rekening hou met God se Skrifopenbaring. (Omdat hy 'n wysgerige historiografie wou hê, was hy krities teenoor metodes wat die geskiedenis van die Filosofie byvoorbeeld slegs geografies of chronologies wou weergee.)

\section{lets oor die metode self}

Volgens Vollenhoven se metode kan 'n mens vasstel (1) wat die verhouding van 'n bepaalde denker se konsepsie tot die Woord van God was of is en hy onderskei daarvolgens drie periodes (voor, tydens en anti- of na die sintese-denke) in die Westerse denke; (2) hoe dit met die omgewing van die tydsgees saamhang (die betrokke wysgerige stroming); (3) wat die verband daarvan met die verlede is of was ('n bepaalde ontologies-antropologiese tipe filosofie).

Die tydstromings (normatiewe beskouings) verander voortdurend. (Vollenhoven het in 1963 al 60 verskillende tydstromings onderskei.) Die rede hiervoor is omdat subjektivistiese wetsidees (wat van dinge of subjekte norme probeer maak) nooit werklik rus kan vind nie (vgl. 'Die rede as leidster' hierbo). Hierdie wissellende filosofiese stromings was of is verantwoordelik vir die dinamiek in die Westerse denkgeskiedenis.

Die verskillende tipes filosofie (ten opsigte van die strukturering van die werklikheid) is egter beperk en kom telkens van geslag tot geslag herhaaldelik na vore (is dus meer konstant), hoewel 'n nuwe stroming ook 'n ou tipe tot 'n mate transformeer.

Volgens hierdie drie hoofonderskeidings sou 'n mens eerstens kon praat van (1) 'n religieuse teenoor mekaarverhouding (bv. die pagane Griekse denke, wat die Bybel nie geken het nie en 'n Christelike filosofie, wat die Skrif probeer gehoorsaam; of die teëstelling tussen die sekulêre en die Christelike antisintetiese denke vanaf die Renaissance en die Reformasie); (2) Tweedens is daar sprake van 'n na mekaarverhouding (die opeenvolgende normatiewe rigtings wat deur stromings of skole voorgestaan word); (3) Derdens is daar 'n langs mekaar-verhouding (verskillende tipes filosofieë oor die struktuur van die werklikheid).

\section{Die waarde van die metode}

'n Belangrike waarde van hierdie soort historiografie is dat dit 'n mens nie alleen 'n globale oorsig oor die ontwikkeling van die Westerse denke bied nie, maar daarmee saam 'n dieper insig daarin gee.

Heelwat meer kan egter daaruit geleer word, byvoorbeeld (1) dat enige filosofie diep religieuse wortels het. 'n Mens kan jou hart aan die rede, die gevoel, mag, nut, vryheid, enigiets in die skepping verpand. Van hierdie verabsoluteerde iets 
verwag 'n mens dan ook (2) om die normatiewe rigting vir jou denke en handelinge aan te toon. In die lig van (1) en (2) kyk jy dan (3) op 'n spesifieke wyse na die werklikheid rondom jou. Augustinus het vantevore gesê dat mense afgode dien, self al meer soos hulle begin lyk en die wêreld rondom hulle volgens hulle eie beeld (wat 'n refleksie van hulle gode is) probeer herskep.

Soos reeds genoem, ontdek Vollenhoven in die lig van die Skrif ook weer die hart van die mens, wat in die loop van die geskiedenis vir allerlei surrogate (bv. intellek, rede, wil) ingeruil is. Behalwe dat sy historiografie wysgerig verantwoord is, spreek dit ook tot die hart van 'n Skrifgelowige denker. Dit inspireer tot grondige kritiek van jou eie en ander se standpunte in die lig van God se openbaring.

Christendenkers moet byvoorbeeld duidelik onderskei tussen hedendaags (kontemporêr) en gangbaar (aanvaarbaar) in plaas daarvan om die twee begrippe te vereenselwig en bloot die gangbare Postmodernisme te aanvaar. Dit wil egter voorkom dat Christene vandag op alle vakgebiede, selfs in die Christelike teologie, soms kritiekloos met die hedendaagse irrasionalisties-postmodernistiese stromings saamdryf.

'n Volgende waarde van die historiografiese metode is dat dit met die nodige aanpassings veel wyer as bloot in die Filosofie, ook op ander vakgebiede gebruik kan word. Enkele voorbeelde hiervan is die teologie, veral dogmatiek en dogmageskiedenis, asook in die hermeneutiek, wetenskappe wat die Westerse kultuurgeskiedenis as veld het (bv. algemene kultuurgeskiedenis, geskiedenis van die estetika en die kunste, geskiedenis van die natuurwetenskappe, ekonomie ens.) en wetenskappe wat sterk deur verskillende mensbeskouings bepaal word (bv. antropologie, psigologiese vakke, sosiale wetenskappe, ens.).

\section{Wat Vollenhoven besiel het}

Volgens die mense wat Vollenhoven geken het, was hy 'n buitengewoon harde werker, wat selfs na sy aftrede op 70 (in 1963) nog 16 uur per dag in sy studeerkamer deurgebring het. Hy het ook nog tot 1975 privaatklasse (privatissima) vir plaaslike en oorsese studente en dosente aangebied. Net om die honderde filosowe wat in sy Schematische Kaarten (vgl. Vollenhoven 2000) opgeneem is, te tipeer, moes hy etlike duisende boeke geraadpleeg het. Wat kon hom begeester het?

Bril en ander filosowe meen dat die dryfkrag in Vollenhoven se lewe - dit wat hy as sy roeping en taak beskou het - die feit was dat hy sowel in sy sistematiese filosofie as in sy historiografie reformatories wou optree. Dit wou hy bewerkstellig deur 'n ontmaskering en bestryding van sintese-denke binne die Christendom:

Hij was overtuigd dat het synthese was met niet-christelijke thema's die de oorzaak waren, ook in de kerkgeschiedenis, van vele moeilijkheden. Door voortgezette ... bestudering van de geschiedenis der wijsbegeerte kon hierdoor een verheldering ontstaan. (Bril 1978:4)

\section{Gebreke by Vollenhoven}

Om te voorkom dat die leser mag dink dat die skrywer Vollenhoven as dié reformatoriese denker bo enige kritiek wil kanoniseer, net die volgende twee opmerkings: Vollenhoven self sou so 'n houding beslis afkeur. Een van sy bekende uitsprake was: 'Moet nooit sweer by die woorde van 'n mens nie.' Soos reeds aangetoon, het hy homself ook beskryf as 'n kind van sy eie tyd en van die gangbare filosofieë van destyds.

Drie moontlike gebreke kan soos volg gestel word:

Vollenhoven het nog hoofsaaklik vanuit 'n Westerse perspektief gedink en in die bestudering van die geskiedenis homself doelbewus ook tot die Westerse denke beperk.

In sy bestudering van die geskiedenis bestaan daar nog meer leemtes. Hy het byvoorbeeld in sy antropologiese besinning myns insiens te min aandag gegee aan menslike geslagtelikheid en die verskillende visies op die verhouding tussen die twee geslagte (bv. geslagtelike polariteit, eenheid en die komplementariteit tussen man en vrou. Vgl. in hierdie verband die boeke van Allen 1985, 2002) Sy probleemhistoriese metode was egter nie bedoel om 'n filosofie of filosofieë uitputtend te beskryf nie (vgl. Van der Walt 2010c:176-177.)

Ongelukkig, maar begryplik (hy is in 1978 oorlede) dek sy probleem-historiese metode nie belangrike, meer resente filosowe in die Westerse denke nie.

\section{Vollenhoven se tipering van sy eie, meer finale filosofiese standpunt}

Na 1945 het Vollenhoven nie verder aan sy eie sistematiese filosofie gewerk nie (vgl. Vollenhoven 2010). Vir die volgende ongeveer 20 jaar van sy lewe het hy al sy aandag aan die bestudering van die geskiedenis van Westerse filosofieë gewy. Die vraag kan dus gestel word hoe Vollenhoven later (na 1945) sy eie filosofie volgens sy probleem-historiese metode sou tipeer.

Vollenhoven het homself ongelukkig nooit heeltemal duidelik oor sy eie standpunt volgens die probleem-historiese metode uitgelaat nie. Hy het wel gesê dat in vergelyking met die verskillende tipes filosofieë wat hy in die Westerse geskiedenis gevind het, hy hom nader aan sekere denkpatrone bevind het, omdat hulle meer reg aan die werklike stand van sake in die werklikheid laat geskied. Dit het hy egter gedoen sonder om van sodanige standpunt 'n ondersteuner te wees (vgl. Van der Walt 2010b).

Hy voel homself byvoorbeeld meer aan die kosmogonokosmologiese denke as die louter-kosmologiese denke verwant, omdat dit groter klem wou lê op die genese, ontwikkeling of dinamiek in die skepping. Hoewel hy krities teenoor sowel ' $n$ monistiese as dualistiese ontologie is, sou hy eerder eersgenoemde verkies. Wat sy mensbeskouing betref, sou hy van al die baie moontlikhede die wisselwerkingsteorie verkies. Dit beteken egter nie die wisselwerking tussen 'n 
hoëre siel en 'n laere liggaam nie, maar dat hy van mening was dat daar wedersydse wisselwerking tussen die innerlike en uiterlike fasette van menswees bestaan.

Van die verskillende soorte wisselwerkingsteorieë sou hy aan die pneumatologiese voorkeur gee, aangesien dit die sentrum (innerlike) van die mens as die pneuma (asem, gees of lewensgees) beskou. Indien hy na 'n spesifieke vroeëre denker se antropologie moes verwys, sou dit Gregorius van Nazianze (329-390) wees. (Vir meer besonderhede, vgl. Van der Walt 2010b:302-305). Dit beteken egter nie dat Vollenhoven met die res van die denke van Gregorius sy instemming sou betuig nie. Hierdie tipe mensvisie kom ook sterk ooreen met Vollenhoven se aanvaarding van die antropologie van Janse, reeds onder 'Invloed van Janse (1890-1960)' hierbo genoem.

\section{Die reaksies van volgende generasies}

Voordat ten slotte iets meer spesifiek gesê word oor die verbintenis tussen die denke van Vollenhoven en Suid-Afrika, word eers in breë trekke nagegaan wat ná Vollenhoven met sy pionierswerk gebeur het. Aangesien hierdie artikel oor Vollenhoven deel is van ' $n$ trilogie oor die drie vaders van ' $n$ reformatoriese filosofie, word hier ook kortliks die reaksies op die filosofieë van Dooyeweerd en Stoker aangestip.

\section{'n Oorsig oor die verskillende fases}

Klapwijk (1980) verdeel die honderdjarige geskiedenis van die Filosofie aan die Vrije Universiteit (1880-1980) in die volgende drie fases: (1) wysgerige verkenning (bv. Kuyper, Woltjer, Geesink, Bavinck \& Pos); (2) wysgerige sistematisering (Dooyeweerd, Vollenhoven \& Zuidema); en (3) wysgerige uitbouing (na Vollenhoven se emeritering in 1963 deur Van Riessen, Begeman, Van der Hoeven, Troost, Klapwijk, Bos, Smit, Griffioen e.a.).

Omdat Klapwijk se oorsig tot Nederland beperk is, het hy by fase 2 nie die naam van Stoker ingesluit nie. Hierdie reeks artikels kyk breër en dus word Stoker bygevoeg. Hierdie artikel oor Vollenhoven en die twee volgendes oor Dooyeweerd en Stoker is tot fase 2 beperk, hoewel dit ook invloede uit fase 1 betrek het. In fase 3 verwag 'n mens dat die nuwe generasie krities oor die werk van hulle voorgangers gedurende fase 2 sal besin en moontlik ' $n$ navolger van een van die driemanskap sal word.

\section{Verdere besinning en skoolvorming}

Van Riessen (vgl. Klapwijk 1980:571) beskou Dooyeweerd se transendentale kritiek as onoortuigend en nie in staat tot kommunikasie met andersdenkendes nie. Hy probeer verder ook die denke van Dooyeweerd en Vollenhoven versoen.

In die geval van ander opvolgers van die drie vaders word egter ' $n$ duideliker keuse vir een van hulle se filosofie binne die familie van reformatoriese denkers gemaak. (Dit moet ook onthou word dat sedert die werk van Klapwijk in 1980 daar alreeds 'n vierde generasie, agterkleinkinders, op die toneel verskyn het.) Soos in die geval van alle ander filosofieë, het ook hierdie drie denkers hulle navolgers gehad, wat in hooftrekke die betrokke (groot-)vader se denke voortgesit, maar tog ook gewysig het. (Dieselfde verskynsel kry 'n mens ook in die teologie, bv. Kuyperiane of Thomiste, asook in ander vakwetenskappe.)

Wolterstorff (1987) skryf in hierdie verband selfs:

$\ldots$ as so often happen in families there was considerable quarreling within the family. We now, looking back, are struck by the similarities ... At that time, however, these figures and their associates and followers were vividly aware of the differences and were loath to admit the similarities. (bl. 25)

Die gemeenskaplike van al drie reformatoriese filosowe waaraan 'n mens behoort vas te hou, formuleer Bril (1978) soos volg:

... dat men geprobeerd heeft ernst te maken met het christelijk geloof ook voor de wetenschap en de wijsbegeerte. Dat men zich verzette tegen een gespletenheid in het leven: een christelijk geloof uitsluitend voor een intieme sector van het persoonlijke leven en een $\mathrm{zg}$. neutraliteit voor de wetenschap en de wijsbegeerte. (bl. 2)

\section{Voorbeelde van navolgers}

'n Mens kan maklik die naamlys van reformatoriese denkers wat Van der Walt (2010a) noem, in navolgers van Dooyeweerd, Vollenhoven en Stoker kon indeel. Dooyeweerdiaanse denkers in Suid-Afrika was of is byvoorbeeld E.A. Venter, P. de B. Kok, D.F.M. Strauss (in Bloemfontein), M.E. Botha (later in Kanada), J.L. van der Walt, M.F. Heyns en R. Coletto (in Potchefstroom). In die geval van die buiteland is daar veel meer name te noem en soms word daar selfs tussen streng (of regse) en gematigde (linkse) Dooyeweerdiane onderskei!

Vollenhoveniaanse of sodanig getinte denkers in Suid-Afrika sou J.A.L. Taljaard, N.T. van der Merwe, J.J. Venter en B.J. van der Walt kon insluit. In die VSA en Kanada sal dieselfde geld van H.E. Runner, C. Seerveld, J.C. van der Stelt, G.J. Spykman, J.H. Kok en R. Sweetman. K.A. Bril en A. Tol is belangrike Vollenhoven-deskundiges in Nederland.

Sover ek weet, vind ' $n$ mens nie Stokeriane buite Suid-Afrika nie, maar binne Suid-Affrika is wel 'n aantal filosowe wat teen sy denke aangeleun het of nog aanleun soos byvoorbeeld S.P. van der Walt, J.A. Heyns, B. Duvenage, P.G.W. du Plessis, A.G.W. Raath en H.G. Stoker (Jnr.).

\section{Voorbeelde van binnegevegte in die tradisie}

Volledigheid ten opsigte van die binnegevegte is heeltemal onmoontlik. Daar word dus volstaan met twee voorbeelde van die manier hoe sekere navolgers op die oorspronklike tradisie - in sommige gevalle byna epigonies - gereageer het. Die volgende kom aan die orde: Malan as verdediger van Dooyeweerd teenoor Stoker, asook Hart en Stoker se eie verweer; twee kampvegters vir Vollenhoven teenoor Dooyeweerd en Stoker. (Die verkenning van Fernhout 1978a; 1978b en 1979 word buite bespreking gelaat.) 
'n Verdediger van Dooyeweerd se filosofie teenoor dié van Stoker

'n Uitstaande voorbeeld hiervan was die Suid-Afrikaner, Malan (1968), se proefskrif aan die Vrije Universiteit wat Stoker vanuit sy Dooyeweerdianisme - dikwels sonder voldoende argumente - van heelwat beskuldig het. (Nie dat hiermee geïmpliseer word dat alles wat hy oor Stoker geskryf het van waarheid ontbloot was nie.) Hart (1971) tree ook in om Stoker te verdedig. Stoker self (vgl. Stoker 1970:411-433) het ook gereageer met 'n uitgebreide antwoord op Malan se beoordeling van sy (Stoker) se filosofie.

\section{Verdedigers van Vollenhoven se denke teenoor Stoker en Dooyeweerd se wysbegeerte}

Steen (vgl. sy werk wat eers in 1983 gepubliseer is) bied in sy proefskrif (1970) 'n kritiese analise van Dooyeweerd se ontologie in die lig van dié van Vollenhoven (vgl. veral Steen 1983:42-106).

Taljaard (1976) gee waardevolle, indringende kommentaar op die filosofie van sowel Dooyeweerd as Stoker en doen dit hoofsaaklik vanuit 'n Vollenhoveniaanse historiografiese vertrekpunt. (Vgl. Taljaard 1976:300-301 waar al die bladsyverwysings na Dooyeweerd en Stoker aangedui word.)

Op bl. 86-87 en bl. 108-111 kritiseer hy byvoorbeeld Stoker se idee van ' $n$ ideostansie, sy fenomenologie en openbaringsidee. Volgens Taljaard, staan Stoker in 'n denktradisie (die subsistensieteorie) wat vanaf Aristoteles, oor Thomas van Aquino (tweede fase), Suarez en Bavinck strek. Dooyeweerd filosofeer volgens Taljaard in 'n monargiaanse denktradisie, wat merkwaardig, ook by Thomas van Aquino (in sy eerste fase) en uiteindelik by Aristoteles aansluit.

\section{Verteenwoordigers van die Vollenhoveniaanse Iyn}

Hierdie gedeelte van die ondersoek word afgesluit deur die aandag weer op die Vollenhoveniaanse lyn te vestig.

Drie reformatoriese filosowe het Vollenhoven goed geken (het as sy assistent opgetree en/of het sy privatissima na sy aftrede vanaf 1963 tot 1975 bygewoon), naamlik K.A. Bril, A. Tol en J.H. Kok.

Bril skryf sy proefskrif (vgl. Bril 1986) oor Vollenhoven se historiografiese metode, maar tree ook op as redakteur of mederedakteur by die (her)uitgawe en vertaling in Engels van verskeie van Vollenhoven se geskrifte (bv. Vollenhoven 1982, 1992, 2000, 2005a, 2005b \& 2011).

Tol skryf heelwat artikels oor Vollenhoven (bv. Tol 2007), promoveer uiteindelik oor die ontwikkeling van sy filosofie (Tol 2010) en tree ook as mederedakteur op vir sommige van Vollenhoven se werke (bv. Vollenhoven 1992, 2005c, 2010).

Ook Kok (1992) skryf 'n proefskrif oor Vollenhoven se vroeë denke, behartig 'n geskiedenis van die Westerse denke volgens Vollenhoven se probleem-historiese metode
(Kok 1998) en tree op as mederedakteur van 'n Engelse (vgl. Vollenhoven 2005c) en 'n tweetalige uitgawe (Nederlands en Engels) van Vollenhoven se sistematiese hoofwerk (Vollenhoven 2005d). Hierdie verkenning word nou afgesluit deur die voorafgaande nader aan die eie huis te bring.

\section{Kontak tussen die denke van Vollenhoven en Suid-Afrika, veral Potchefstroom}

Hier word kortliks aangetoon dat Vollenhoven en die filosofiese tradisie wat hy begin het nie iets vreemds in SuidAfrika hoef te wees nie. Die volgende historiese gegewens word onder andere genoem:

Stoker raadpleeg Vollenhoven reeds vroeg in die twintigerjare (1922) van die vorige eeu oor verdere studie in Europa.

Sáám werk hulle later - al was hulle resultate ook hoe verskillend - aan die uitbou van 'n reformatoriese filosofie. (Heelwat korrespondensie tussen hulle lê nog onontgin in argiewe.)

J.A.L. Taljaard (1915-1994) van die PU vir CHO promoveer daarna onder Vollenhoven oor Brentano as wysgeer (vgl. Taljaard 1955).

Vollenhoven bied op uitnodiging van die PU vir $\mathrm{CHO}$ in 1963 ongeveer 25 gaslesings op Potchefstroom aan asook 'n paar op Bloemfontein.

N.T. van der Merwe (1932-2004), ook van die Departement Filosofie aan die PU vir $\mathrm{CHO}$, word Vollenhoven se assistent en sorg dat die eerste uitgawe van Vollenhoven se Schematische Kaarten in 1962 die lig sien (vir 'n resente heruitgawe, vgl. Vollenhoven 2000).

B.J. van der Walt woon vanaf 1968-1970 in Amsterdam Vollenhoven se privaatklasse na sy aftrede by; so ook P. van Veuren (RAU) gedurende 1969 en J.J. Venter gedurende 1973-1974.

Bril (1986) promoveer oor Vollenhoven se probleemhistoriese metode en gee in 1987 'n aantal lesings daaroor op Potchefstroom en Bloemfontein.

Verskillende werke wat vanaf 1992 oor en van Vollenhoven die lig sien, vind hulle weg ook na Potchefstroom (vgl. literatuurverwysings).

Op 15 Augustus 2011, by 'n spesiale Vollenhoven Colloquium aan die Vrije Universiteit van Amsterdam, word die gaslesings wat Vollenhoven in 1963 aan die PU vir CHO op Potchefstroom gegee het (vanaf bandopnames oorgetik en daarna geskandeer en geredigeer) deur Bril (een van die redakteurs) uiteindelik bekendgestel en aan verskillende persone oorhandig (vgl. Vollenhoven 2011). Een van die kopieë daarvan word aan prof. M.F. Heyns (Direkteur 
van die Skool vir Filosofie aan die NWU) gegee met die versoek dat dit in Engels vertaal en gepubliseer sal word (heelwaarskynlik in Suid-Afrika, die VSA en Nederland).

Op hierdie wyse word die deurlopende kontak van ongeveer 90 jaar - 'n lang tradisie - tussen Vollenhoven en SuidAfrikaanse denkers voorlopig voltooi. Ek sê voorlopig voltooi, maar nie afgesluit nie. Mag Vollenhoven - 'n groot geleerde, maar terselfdertyd 'n nederige Christen - se kosbare nalatenskap, asook die reformatoriese tradisie in die algemeen nog vir lank ook op Afrikabodem vrugte dra. Mag die ideaal van 'n lewende tradisie, wat aan die begin van hierdie verkenning gestel is, 'n werklikheid wees.

\section{Erkenning}

Met waardering opgedra aan Dr K.A. Bril (Nederland) by die herdenking van sy 80e verjaarsdag - van hom het ek veel oor Vollenhoven kon leer.

\section{Mededingende belange}

Die outeur verklaar dat hy geen finansiële of persoonlike verbintenis het met enige party wat hom nadelig kon beïnvloed in die skryf van hierdie artikel nie.

\section{Literatuurverwysings}

Allen, P., 1985, The concept of woman, vol. 1, Eerdmans, Grand Rapids, Michigan Allen, P., 2002, The concept of woman, vol. 2, Eerdmans, Grand Rapids, Michigan. Bavinck, H., 1906, Bilderdijk als denker en dichter, Kok, Kampen.

Bertels, C.P., 1972, 'Michael Foucault', in C.P. Bertels \& E. Petersma (reds.), Filosofen van de 20e eeu, bl. 211-224, Van Gorcum, Assen.

Bosch, J., 1961, 'Willem Bilderdijk als wijsgerig historievormer', in W.D. van Dijk \& J. Stellingwerff (reds.), Perspectief, bl. 228-240, Kok, Kampen.

Bril, K.A., 1978, 'Vollenhoven en de reformatie der wijsbegeerte', Nieuw Nederland, bl. 1-4, Junie.

Bril, K.A., 1986, Westerse denkstructuren: Een probleemhistorisch onderzoek, VUUitgeverij, Amsterdam. PMid:3958117

Chaplin, J., 2011, Herman Dooyeweerd: Christian philosopher of state and civil society, University of Nortre Dame Press, Nortre Dame, Indiana.

Derksen, L.D., 1983, Universal hermeneutics: A study in the philosophy of Hans-Georg Gadamer, VU Boekhandel, Amsterdam.

Fernhout, H., 1978a, 'Man, faith and religion in Bavinck, Kuyper and Dooyeweerd' Tydskrif vir Christelike Wetenskap 14, 74-91.

Fernhout, H., 1978b, 'Man, faith and religion in Bavinck, Kuyper and Dooyeweerd', Tydskrif vir Christelike Wetenskap 15, 54-71.

Fernhout, H., 1979, 'Man, faith and religion in Bavinck, Kuyper and Dooyeweerd', Tydskrif vir Christelike Wetenskap 15, 119-140.

Glas, G., 2011, Twijfel, bewijs en overgave: Over christelijke filosofie, Sjibbolet, Amsterdam.

Groen Van Prinsterer, G., 1951, Ongeloof en revolutie: Een reeks historische voorlezingen, in H. Smitskamp (red.), Wever, Franeker.

Groen Van Prinsterer, G., 1973, Lecture eleven from 'Unbelief and revolution', in H. van Dyke (transl. \& ed.), The Groen van Prinsterer Fund, Amsterdam.

Groen Van Prinsterer, G., 1975, Lectures eight and nine from 'Unbelief and revolution', in H. van Dyke (transl. \& ed.), The Groen van Prinsterer Fund, Amsterdam.

Hart, H., 1971, 'Malan's critical study', in H.J.J. Bingle (ed.), Truth and reality: Philosophical perspectives on reality dedicated to prof. dr. H.G. Stoker, pp. 109-121, De Jong's Bookshop, Braamfontein.

Heslam, P.S., 1998, Creating a Christian worldview: Abraham Kuyper's Lectures on Calvinism, Eerdmans: Grand Rapids, Michigan.

Heyns, M.F., 2002, 'The transformation of the concept "self" with specific reference to the work of Charles Taylor', PhD thesis in Philosophy, Free University.

Ive, J., 2012, 'A critically comparative Kuyperian analysis and in trinitarian perichoretic reconstruction of the reformational philosophies of Dirk H.T. Vollenhoven and Herman Dooyeweerd', PhD thesis in Theology, Free University.
Klapwijk, J., 1980, 'Honderd jaar filosofie aan de Vrije Universiteit', in M. van Os \& W.J. Wieringa (reds.), Wetenschap en rekenschap 1880-1980; een eeuw van wetenschapseoefening en wetenschapsbeschouwing aan de Vrije Universiteit, wetenschapsbeoefening en
bl. 529-593, Kok, Kampen.

Klapwijk, J., 1987, Kijken naar kopstukken, Buijten \& Schipperheijn, Amsterdam.

Klapwijk, J., 1992, 'Een beminnelijk mens, een eminente geleerde', Beweging 56, 87-90.

Kluit, M.E., 1960, 'Réveil', in F.W. Grosheide \& G.P. van Itterzon (reds.), Christelijke encyclopedie, bl. 627-629, Kok, Kampen.

Kluit, M.E., 1970, Het Protestantse Réveil in Nederland en daarbuite, 1815-1865, Paris, Amsterdam.

Kok, J.H., 1992, Vollenhoven; his early development, Dordt College Press, Sioux Center, lowa.

Kok, J.H., 1998, Patterns of the Western mind: A reformed Christian perspective, Dordt College, Sioux Center, lowa.

Kok, J.H., 2007, 'Woltjer on Classical Antiquity', in R. Sweetman (ed.), In the Phrygian Mode: Neo-Calvinism, antiquity and the Lamentations of reformationa philosophy, pp. 13-26, ICS \& Lanham: University Press of America, Toronto.

Kuyper, A., 1899, Calvinism: Six Stone-lectures, Höveker \& Wormser, Amsterdam.

Malan, D.J., 1968, 'n Kritiese studie van die wysbegeerte van H.G. Stoker vanuit die standpunt van H. Dooyeweerd, Buijten \& Schipperheijn, Amsterdam. PMCid:1187029

Middleton, J.R. \& Walsh, B.J., 1995, Truth is stronger than it used to be: Biblical faith in a postmodern age, InterVarsity, Downers Grove.

Nijhoff, R., 2011a, 'Jan Woltjer on logos, order and knowledge', paper presented at the International Symposium of the Association for Christian Philosophy, Amsterdam, 16-19 August 2011.

Nijhoff, R., 2011b, 'Jan Woltjer's logos theory and its legacy', paper presented at the International Vollenhoven Colloquium at the Free University, Amsterdam, 15 August 2011.

Overduin, J., 1957, 'Costa, Isaac da', in F.W. Grosheide \& G.P. van Itterzon (reds.), Christelijke encyclopedie, Deel 2, bl. 307-308, Kok, Kampen.

Pelikan, J., 1984, The vindication of tradition, Yale University Press, New Haven.

Puchinger, G., 1980, Gesprekken over honderd jaar Vrije Universiteit, W.D. Meinema, Delft.

Runner, H.E., 1982, The relation of the Bible to learning, Paideia, Jordan Station, Ontario. PMid:6190973

Scholten, L.W.G., 1958, 'Groen van Prinsterer, Guillaume', in F.W. Grosheide \& G.P. van Itterzon G.P. (reds.), Christelijke encyclopedie, Deel 3, bl. 312-313, Kok, Kampen.

Schutte, G.J., 1977, Mr. G. Groen van Prinsterer, Oosterbaan \& Le Cointre, Goes.

Smilde, S., 1956, 'Bilderdijk, Willem', in F.W. Grosheide \& G.P. van Itterzon (reds.), Christelijke encyclopedie, Deel 1, bl. 651-653, Kok, Kampen.

Steen, P.J., 1983, The structure of Herman Dooyeweerd's thought, Wedge Publishing Foundation, Toronto.

Stellingwerff, J., 1992, D.H.Th. Vollenhoven (1892-1978): Reformator der wijsbegeerte, Ten Have, Baarn.

Stoker, H.G., 1961, Beginsels en metodes in die wetenskap, Pro Rege, Potchefstroom.

Stoker, H.G., 1970, Oorsprong en rigting, Deel 2, Tafelberg, Kaapstad.

Strauss, D.F.M., 2009, Philosophy: Discipline of the disciplines, Paedeia Press, Grand Rapids, Michigan.

Taljaard, J.A.L., 1955, Franz Brentano as wijsgeer, Wever, Franeker.

Taljaard, J.A.L., 1976, Polished lenses, Pro Rege Press, Potchefstroom. PMid:964808

Tol, A., 2007, 'Vollenhoven on early classical antiquity', in R. Sweetman (ed.), In the Phrygian Mode: Neo-Calvinism, antiquity and the lamentations of reformational philosophy, pp. 127-160, University Press of America, Lanham.

Tol, A., 2010, 'Philosophy in the making': D.H.Th. Vollenhoven and the emergence of reformed philosophy, Dordt College Press, Sioux Center, lowa.

Tol, A., 2011, 'Reformational philosophy in the making', Philosophia Reformata 76, 187-214.

Van der Laan, H., 2000, Jan Woltjer (1849-1917): Filosoof, classicus, pedagoog, VUUitgeverij, Amsterdam.

Van der Walt, B.J., 2008a, 'Antheunis Janse van Biggekerke (1890-1960); morning star of a reformational worldview', in B.J. van der Walt (ed.), The eye is the lamp of the body, pp. 189-229, The Institute for Contemporary Christianity in Africa, Potchefstroom.

Van der Walt, B.J., 2008b, 'The historical background of the postmodern view on normativity and on a Christian worldview', in B.J. van der Walt (ed.), The eye is the lamp of the body, pp. 128-166, Institute for Contemporary Christianity in Africa, Potchefstroom.

Van der Walt, B.J., 2010a, 'An overview of the global presence of a Christian reformational philosophy and scholarship', in B.J. van der Walt (ed.), At home in God's world, pp. 127-151, Instititute for Contemporary Christianity in Africa, Potchefstroom.

Van der Walt, B.J., 2010b, 'The human heart rediscovered in the anthropology of D.H.Th. Vollenhoven', in B.J. van der Walt (ed.), At home in God's world, pp. 290324 , The Institute for Contemporary Christianity in Africa, Potchefstroom. 
Van der Walt, B.J., 2010c, "'A new paradigm for doing Christian philosophy", D.H.Th Vollenhoven (1892-1978)', in B.J.van der Walt (ed.), At home in God's world, pp. 152-182, The Institute for Contemporary Christianity in Africa, Potchefstroom.

Van der Walt, B.J., 2010d, 'Besit waardes enige rigtinggewende waarde?', Koers 75(2), 293-324.

Van der Walt, B.J., 2010e, 'Die waarde van waardes', Koers 75(4), 709-750. http:// dx.doi.org/10.4102/koers.v75i4.104

Van der Walt, B.J., 2010f, 'Normatiwiteit op 'n cul de sac: 'n Reformatoriese visie op wette, norme, waardes en deugde', Tydskrif vir Christelike Wetenskap 46(3\&4), $35-58$.

Van der Walt, M.F., 2009, 'The value of Stoker's methodology for reformational philosophy', unpublished dissertation for Honours in Philosophy, North-West University.

Van Dijk, W.K. \& Stellingwerff, J. (reds.), 1961, Perspectief: Feestbundel van de jongeren bij het vijfentwintig jarig bestaan van de Vereniging voor Calvinistische Wijsbegeerte, Kok, Kampen.

Van Dyke, H., 1989, Groen van Prinsterer's lectures on 'Unbelief and Revolution' Wedge Publishing Foundation, Jordan Station, Ontario.

Van Dyke, H., 2001, 'Standing in the Kuyperian tradition', in J. Kok (ed.), Marginal resistence: Essays dedicated to J.C. Vander Stelt, pp. 1-23, Dordt College Press, Sioux Center, lowa.

Venter, J.J., 1981, ‘Geloofsgebonde denke by Anselmus: 'n Studie van sy wysgerige metode', DPhil proefskrif, PU vir CHO.
Vollenhoven, D.H.Th., 1918, De wijsbegeerte der wiskunde vanuit theïstische standpunt, Wed. G. Van Soet, Amsterdam.

Vollenhoven, D.H.Th., 1982, Vollenhoven's laatste werk, in K.A. Bril (red.), VU Boekhandel, Amsterdam.

Vollenhoven, D.H.Th., 1992, Vollenhoven als wijsgeer: Inleidingen en teksten, in A. Tol \& K.A. Bril (reds.), Buijten \& Schipperheijn, Amsterdam. PMCid:474797

Vollenhoven, D.H.Th., 2000, Schematische kaarten: Filosofishe concepties in probleemhistorisch verband, in K.A. Bril \& P.J. Boonstra (reds.), De Zaak Haes, Amstelveen. PMCid:101543

Vollenhoven, D.H.Th., 2005a, The problem-historical method and the history of philosophy, in K.A. Bril (ed.), De Zaak Haes, Amstelveen.

Vollenhoven, D.H.Th., 2005b, Wijsgerig Woordenboek, in K.A. Bril (red.), De Zaak Haes, Amstelveen

Vollenhoven, D.H.Th., 2005c, Isagôgè philosophiae: Introduction to philosophy, in J.H. Kok \& A. Tol (eds.), Dordt College Press, Sioux Center, lowa.

Vollenhoven, D.H.Th., 2005d, Isagôgè philosophiae: Introduction to philosophy (bilingual edn.), in J.H. Kok \& J. Tol (eds.), Dordt College Press, Sioux Center, lowa.

Vollenhoven, D.H.Th., 2010, Isagôgè philosophiae 1930-1945 (tekskritische uitgave): Filosofie in de traditie van de Reformatie, in A. Tol (red.), VU-Uitgeverij, Amsterdam.

Vollenhoven, D.H.Th., 2011, Gastcolleges Wijsbegeerte: Erfenis voor het heden, in K.A. Bril \& R.A. Nijhoff (reds.), De Zaak Haes, Amstelveen.

Wolterstorff, N.P., 1987, Keeping faith: Talks for new faculty at Calvin College, Calvin College Press, Grand Rapids, Michigan. 